\title{
Improving the Quality of Education - a Vision for Knowledgeable, Creative and Responsible Students
}

\section{Izglītības kvalitātes paaugstināšana - vīzija par zinošiem, radošiem un atbildīgiem studentiem}

\author{
Sarmīte Čerņajeva \\ Rīgas Tehniskā universitāte, Latvija
}

\begin{abstract}
Anotācija - Visā pasaulē jautājumi, kas saistīiti ar izglītības sistēmas efektivitāti un kvalitāti, ir ḷoti aktuāli. Sākot no nākamā, 2018./2019. mācību gada, skolās un pirmsskolas iestādēs (bērniem vecumā no 1,5 līdz 18 gadiem) Latvijā sāks pakāpenisku pāreju uz uzlabotu izglītības saturu un atbilstošu mācību metožu maiṇu, kā rezultātā skolēni attīstīs zināšanas, prasmes un attieksmes atbilstoši 21. gadsimta vajadzībām. Valsts izglīīibas programmas (VISC) projekts "Kompetences pieeja mācību saturam" paredz izveidot atbalsta mehānismus skolām un skolotājiem, pašvaldībai un vecākiem, lai piecu gadu laikā veiksmīgi mainītu mācību metodes.
\end{abstract}

Atslēgas vārdi - Attieksme, matemātika, mācību process, mācǐšanas pieeja.

\section{IEVADS}

Informacionālā revolūcija, par ko tik bieži tiek runāts, ne tikai izmaina ikdienas darbu, bet arī ievieš jaunu domāšanu, būtiskas izmaiṇas ne tikai sabiedrībā un politikāa, bet arī pasaules redzējumā [1]. Inženieri darba tirgū ir novērtēti un pieprasīti, tāpēc jauno inženieru kvalitatīvai izglītībai profesionālajā darbībā ir svarīga nozīme valsts nākotnē. Pieredze rāda, ka studēt ir daudz vieglāk, ja ir uzkrātas labas pamatzināšanas eksaktajos priekšmetos. Strādājot par matemātikas pasniedzēju Būvniecības fakultātē, darbā arī šobrīd aktualizējas jautājums par iegūto matemātikas zināšanu pielietojumu speciālistu profesionālajā darbībā. Tiek meklētas atbildes uz jautājumiem: kas ir tas, kas jāmāca, un kā tas jādara, lai iegūtās matemātikas zināšanas būtu noderīgas profesionālajā darbībā.

\section{CENTRALIZĒTAIS EKSĀMENS MATEMĀTIKĀ}

Obligātais centralizētais eksāmens (CE) matemātikā tika ieviests 2008./2009. mācību gadā. Profesionālo izglītības iestāžu skolēni arī kārto matemātikas eksāmenu, jo tā saturs ir veidots tā, lai matemātiskās prasmes varētu pārbaudīt arī profesionālās vidējas izglītības iestāžu audzēkṇi.

Matemātikas centralizētā eksāmena darbs sastāv no trim daḷām. Pirmajā daḷā, kur pārbauda zināšanas un pamatprasmes, ir 15 atbilžu izvēles uzdevumi un 10 īso atbilžu uzdevumi. Kopā ir 25 uzdevumi, kur par katru uzdevumu var iegūt 1 punktu. Otrajā daḷā skolēni pārbauda savu zināšanu pielietojumus standarta uzdevumos. Tiek dotas 10 matemātikas uzdevumi, par kuru atrisināšanu tiek iegūti 40 punkti. Trešajā daļā skolēni pārbauda zināšanu pielietojumus nestandarta situācijās. Kopā jārisina trīs izvērsti uzdevumi, par kuru atrisināšanu tiek iegūti 15 punkti.

Kā eksāmens matemātikā tiek vērtēts? Ja

1. daḷā iegūti 20 punkti no 25 maksimālajiem, kas sastāda $80 \%$,

2. daḷā iegūti 28 punkti no 40 maksimālajiem, kas ir $70 \%$,

3. daḷā iegūti 9 punkti no 15 maksimālajiem, kas ir $60 \%$, tad kopvērtējums veidojas no izteiksmes $(20+28+9=57) / 80$ (maksimālais iespējamais punktu skaits), kas ir $71 \%$ no darba.

Eksāmenu matemātikā šogad kārtoja nedaudz vairāk nekā 13300 skolēnu [2] (1. att.). Pēc Valsts izglītības satura centra apkopotās informācijas, centralizētajā eksāmenā matemātikā 12. klases skolēniem šogad vidēji izdevies sasniegt 34,9\%, kas ir par 1,3 procentiem mazāk nekā iepriekšèjā mācību gadā (2. att.).

Iepriekšējo mācību gadu CE rezultātu analīze ir pierādījusi, ka valstī kopumā skolēni nav sasnieguši pietiekamu standarta matemātisko prasmju līmeni (algoritmiskās zināšanas), kuru katrs matemātikas skolotājs mēgina attīstīt un apmācīt mācību procesā .

Tas pats attiecas uz skolēnu rezultātiem uzdevumos, kuri prasa jēdzienu izpratni. Studentu nespēja tikt galā ar loǵiskajiem uzdevumiem ir biedējoša. Tomēr to nevar saukt par jaunumu, jo iepriekšējo gadu ne tikai matemātisko zināšanu analīze liecina, ka skolēni spēj apgūt relatīvi labi mācību priekšmetu, taču viniiem ir problēmas ar iegūto zināšanu izmantošanu. Ar̄̄ skolēnu neveiksme loǵikas uzdevumos pierāda, ka nepieciešams mainīt mācīšanas metodiku [5]. 


\section{Rezultātu sadalījums matemātikas eksāmenā}

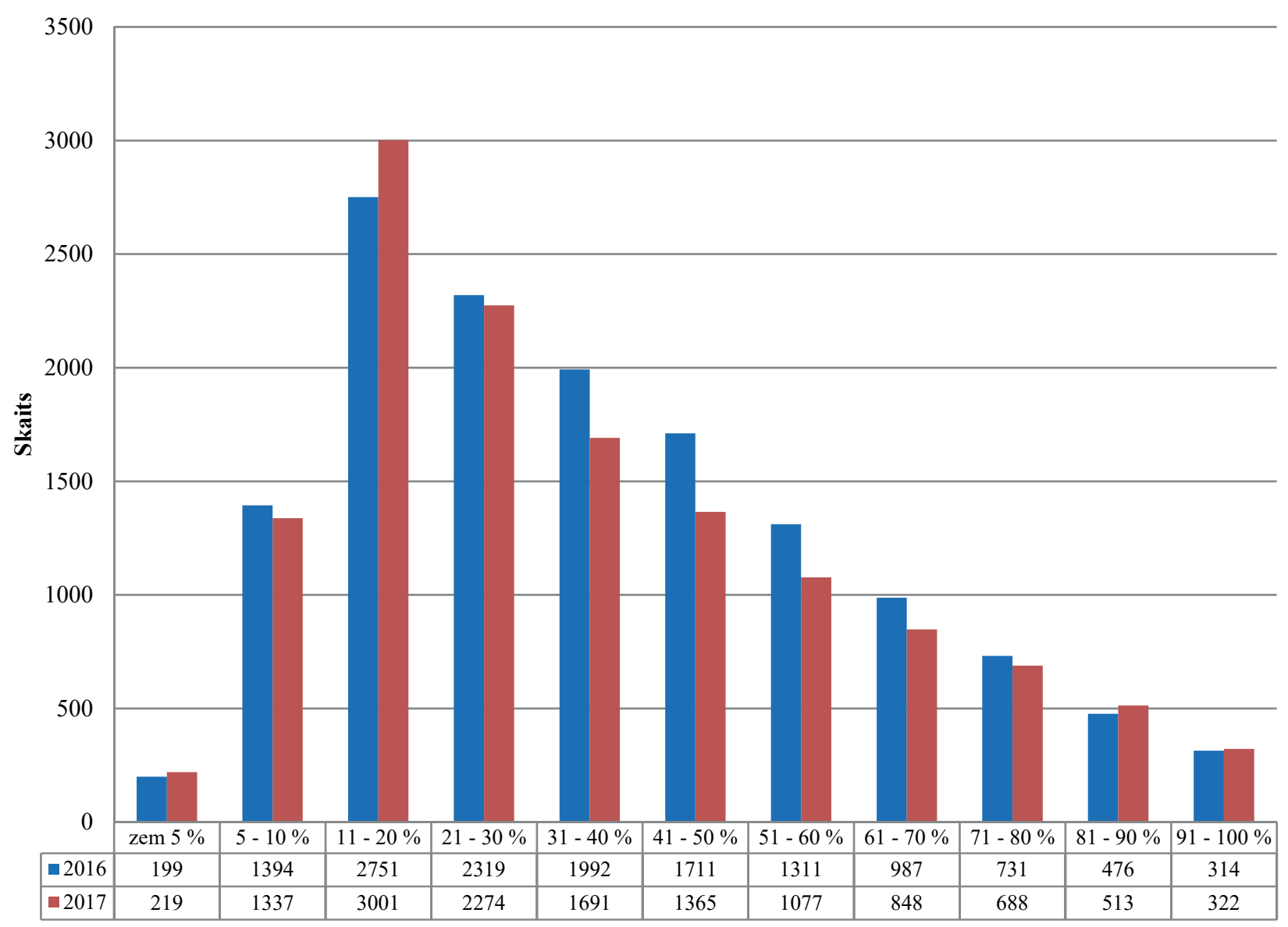

1. att. Apkopotā informācija centralizētajā eksāmenā matemātikā 12. klases.

$43,6 \%$

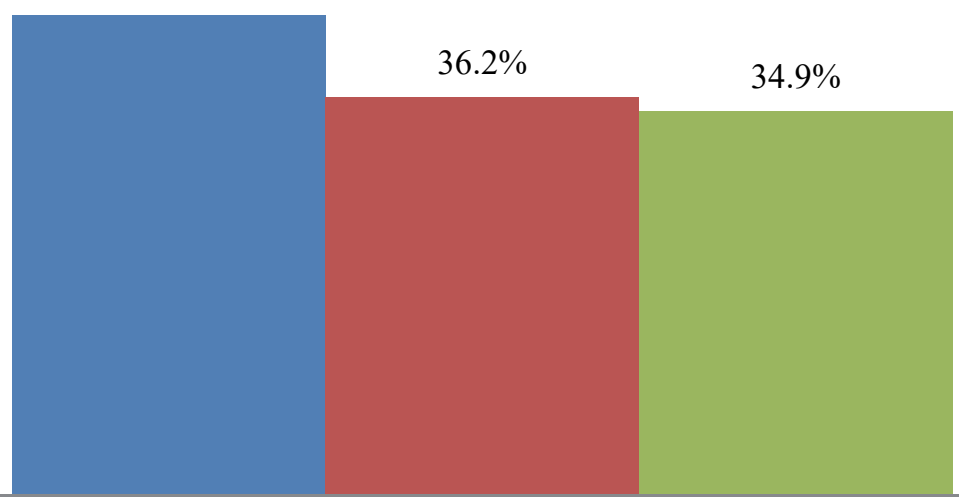

Matemātika

घ2015. $\square 2016 . \quad \square 2017$.

2. att. 12. klašu CE vidējo rezultātu salīdzinājums matemātikā no 2015. līdz 2017. gadam. 


\section{DISKUSIJA}

Sākot ar nākamo - 2018./2019. mācību gadu, skolās un pirmsskolās (bērniem vecumā no 1,5 līdz 18 gadiem) Latvijā tiks sākta pakāpeniska pāreja uz pilnveidotu mācību saturu un tam atbilstošu mainītu mācīšanas pieeju, lai rezultātā skolēni attīstītu dzīvei 21. gadsimtā svarīgas zināšanas, prasmes un attieksmes [3]. Valsts izglītības satura centra projekts "Kompetenču pieeja mācību saturā" ietver izglītības satura izstrādi un aprobāciju, mācību programmu, mācību un metodisko līdzekḷu izstrādi. Tiek paredzēts, ka piecos gados tiks izveidoti atbalsta mehānismi skolotājiem, skolām un vecākiem sekmīgai mācīšanas pieejas maiņai.

Kompetenču pieejā balstîta mācību satura ieviešana tiks uzsākta pakāpeniski [3]:

2018./2019. m. g. pirmsskolā, 1. un 4. klasē,

2019./2020. m. g. - 2., 5., 7. un 10. klasē,

2020./2021. m .g. - 3., 6., 8. un 11. klasē,

2021./2022. m. g. - 9. un 12. klasē.

İstenojot kompetences pieeju, tiks saglabāta mācību priekšmeta programma, taču pastiprināsies skolotāju sadarbība skolas līmen̄i, mācību darba plānošanā un īstenošanā. "Pārmaiņas ir nepieciešamas, jo mainījies ir pats skolēns!" [4]. Ir nepieciešams pāriet no gatavu zināšanu nodošanas un frontālas mācīšanas formas, kur pedagogs klases priekšā sniedz informāciju, uz mācīšanās vadīšanu. Mācīt un mācīties citādi var jau esošā satura ietvaros, un daudzās skolās tas notiek.

"Zināšanas, prasmes un attieksmes ir tie komponenti, kas mums jāaptver, izstrādājot jaunu kompetenču pieejā balstītu izglīîibas saturu. Tā ir atslēga skolēnu panākumiem gan mācībās, gan profesijas apguvē", sacīja Valsts izglītības satura centra vadītājs Guntars Catlaks [6].

\section{MATEMĀTIKA RTU}

Daudziem Rīgas Tehniskajā universitātē (RTU) uzṇemtajiem studentiem elementārās matemātikas zināšanas nav pietiekami labā līmen̄i, lai sekmīgi studētu Augstāko matemātiku un citus eksaktos un tehniskos priekšmetus. Pirmajā matemātikas nodarbībā universitātē veicot studentu elementārās matemātikas zināšanu pārbaudi, konstatējam, ka gandrīz puse no studentiem nespēj atrisināt pat divus no pieciem vienkāršiem uzdevumiem. Kā jau minēts, pārbaudes darbs satur piecus vienkāršus uzdevumus: darbības ar daļskaitliem, funkcijas vērtības aprēķināšana, mainīgā izteikšana no lineāras sakarības, pakāpju pamatīpašības un logaritmu pamatīpašības. Par katru pareizi atrisinātu uzdevumu tiek dotas 2 balles. Pārbaudes darbs skaitās nokārtots sekmīgi, ja students iegūst vismaz 4 balles.
Šāda prakse aicināt uz papildus matemātikas lekcijām studentus ar vājākām zināšanām šajā priekšmetā ilgst jau vairāk nekā piecus gadus. Ja iepriekš RTU šīs lekcijas piedāvāja kā izvēli, tad no 2016./2017. mācību gada visiem studentiem, kuri gada sākumā pietiekami labi nenokārto matemātikas testu, jāapmeklē papildus nodarbības. Tātad RTU nepiel̦auj, ka studenti pabeigs augstskolu ar nepilnīgām matemātiskās zināšanām.

\section{SECINĀJUMI}

1. Eksāmenu vajadzētu sadalīt vairākos līmeņos. Viens variants būtu tiem, kuri vēlas studēt tālāk augstskolā, cits tiem, kuri vēlas apgūt profesiju augstākās profesionālās izglītības mācību iestādē. Savukārt tad, ja absolventi izdomā studēt augstskolā, tad nopietnāko eksāmenu būtu iespējams kārtot arī nākošajā mācību gadā.

2. Mācot matemātiku tiek atbalstīta matemātikas programmu (MathCad, MatLab u.c.) izmantošana studiju procesā, un ieteikts studentiem vairāk mācīt matemātikas pielietojamību.

\section{LITERATŪRAS SARAKSTS}

[1] P. F. Drucker, Managing in the Next Society. Oxford: ButterworthHeinemann, 2003.

[2] Valsts Izglīīibas satura centrs, "Valsts pārbaudes darbi 2016./2017. m. g.," [Online]. Available:

http://visc.gov.lv/vispizglitiba/eksameni/statistika/2017

[3] Skola 2030, "Izglīîiba mūsdienīgai lietpratībai: mācību satura un pieejas apraksts," [Online]. Available: https://www.skola2030.lv

[4] Iespēju tilts, "Darīt vēl labāk," [Online]. Available: http://www.iespejutilts.lv

[5] "Eiropas Sociālā fonda projekta iesniegums," [Online]. Available: http://visc.gov.lv/visc/projekti/dokumenti/esf_831/20161101_apraksts.pdf

[6] "Skolas Vārds" Nr. 15(95), [Online]. Availab̉le: http://www.videsfonds.lv/documents/urn-s-skolas-v-rds-5.pdf.

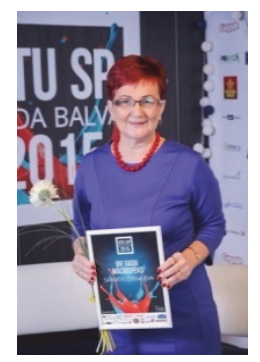

Sarmīte Čerņajeva was born in Gulbene, Latvia. She received the Diploma in Mathematics from the University of Latvia in 1984, and Master's Degree in Education Sciences from the Pedagogical Academy of Liepaja in 2003. Since 2008 she is a Doctoral student of Latvia University of Agriculture.

Now she is a lecturer at the Department of Engineering Mathematics at Riga Technical University.

Her research interests include issues of mathematical pedagogy.

She is a member of the Latvian Mathematical Society. Together with colleagues the research results and practical experience in the development of mathematical competencies in the Baltic States was shared in the monograph (2014) "Transnational Comparative Study on the Math Educational Needs in Baltic States". The monograph summarises the opinion of the inhabitants of the Baltic States about the role of mathematics in the professional and personality development.

E-mail: sarmite.cernajeva@rtu.lv

\section{Improving the Quality of Education - a Vision for Knowledgeable, Creative and Responsible Students Sarmīte Černajeva}

Riga Technical University, Latvia

Issues of improving the efficiency, effectiveness and quality of the education system are very topical in the current process of change around the world. Starting with the next - 2018/2019 - school year in the Latvian schools and preschools (from 1.5 to 18 years) a gradual transition to the improved content of education and the corresponding change of teaching approach will begin. As the result, pupils will develop knowledge, skills and attitudes important for life in the 21 st century. The National Curriculum (VISC) project, "A Competency Approach to Learning Content", provides for the creation of support mechanisms for schools and teachers, municipality and parents to successfully change the teaching approach within five years.

Keywords - Attitude, mathematics, teaching approach, learning process. 